\title{
ANALISIS FUZZY SUGENO DALAM MENENTUKAN PEMILIHAN MOTOR HONDA
}

\author{
Khairul Saleh, Helmi Fauzi Siregar, Zunaida Sitorus \\ Program Studi Teknik Informatika, Universitas Asahan \\ Jl. Jend. Ahmad Yani, Kisaran \\ khairulsibungsu@yahoo.com, fauzi.helmi.hf@gmail.com,z_sitorus@yahoo.com
}

\begin{abstract}
Motorcycles are two-wheeled vehicles. Honda is one of the best selling motorcycle brands in Indonesia. Honda is a Japanese company that has been very tested in Indonesia. Honda also has many types, because of the many types of Honda motorcycles, a decision support system (DSS) with the fuzzy Sugeno method is needed in overcoming the selection of Honda motorcycles. At the same time to compare previous research that has been done with the Mamdani method in determining the selection of the Honda motorcycle.
\end{abstract}

Keywords - Decision Support System, Sugeno, Honda Motor.

\begin{abstract}
Abstrak - Sepeda motor merupakan kenderaan roda dua. Honda merupakan salah satu merek sepeda motor Terlaris di Indonesia. Honda merupakan perusahaan jepang yang sudah sangat teruji yang ada di indonesia. Honda juga mempunyai banyak tipe, oleh karena banyaknya tipe Sepeda motor Honda, dibutuhkan sistem pendukung keputusan( SPK) dengan metode fuzzy sugeno dalam mengatasi pemilihan sepeda motor Honda tersebut. Sekaligus untuk membandingkan penelitian terdahulu yang pernah dilakukan dengan metode mamdani dalam menentukan pemilihan motor Honda tersebut.
\end{abstract}

Kata Kunci - SPK, Sugeno, Motor Honda.

\section{PENDAHULUAN}

Pada zaman sekarang ini, dalam menganalisis suatu penilaian dibutuhkan suatu metode agar keakuratan dalam menentukan hasil sesuai dengan yang diharapkan sehingga kecurangan dalam penentuan hasil akhir dapat terhindari.

Sepeda motor merupakan kendraan yang roda dua yang mempunya beberapa merek yang ada di Indonesia. Salah satu merek yang ada diindonesia adalah merek Honda. Honda merupakan perusahaan jepang yang sudah sangat teruji yang ada diindonesia.

Dari penelitian terdahulu yangberhubbungan dengan penelitian ini, pernah dilakukan oleh Arief Rusman dengan judul "Logika Fuzzy Tahani Sistem Penunjang Rekomendasi Penentuan pemilihan motor Honda “. Begitu juga dari penelitian Januardi Nasirdan ,Johnson Suprianto dengan judul Analisis Fuzzy Logic Menentukan Pemilihan Motor Honda Dengan Metode Mamdani. Berdasarkan penelitian diatas, dapat disimpilkan bahwa penggunaan fuzzy sangat cocok dalam menyelesaikan kasus ini, sehingga peneliti tertarik untuk melanjutkan penelitian dengan metode fuzzy sugeno untuk menghasilkan perbandingan hasil. Dari latar belakang tersebut maka penulis tertarik untuk melakukan peneltian serupa tetapi dengan metode yang berbeda. Oleh karena itu, peneliti ingin mengangkat tema yang berjudul "ANALISIS FUZZY SUGENO DALAM MENENTUKAN PEMILIHAN MOTOR HONDA ".

\section{Rumusan Masalah}

1. Bagaimana membuat Fuzzy Rule Base dengan operator And pada kasus ini?

2. Bagaimana menerapkan fuzzy sugeno dalam penyelesaian kasus ini dengan Matlab 2014a?

\section{A. Logika Fuzzy}

Dalam penelitian Kusumadewi \& Purnomo (2010) logika fuzzy adalah komponen dari soft computing yang diperuntukkan sebagai cara untuk memetakan permasalahan dari input menjadi output yang diinginkan. Begitu juga dalam hal prediksi.

Logika Fuzzy adalah konsep untuk menangani masalah nonlinear, waktu yang bervariasi, dan sistem adaptif. Sistem cerdas berdasarkan logika fuzzy sering digunakan dalam memilah proses untuk mendeteksi cacat dalam implementasinya. (Hosseinzadeh. 2011)

Berdasarkan referensi diatas, dapat dikatakan bahwa Logika fuzzy merupakan suatu sistem matematika yang dapat menyelesaikan ketidakpastian sehingga dapat digunakan dalam mempridiksi kemasa depan.

\section{B. Inferensi}

Fungsi dari Inferensi yaitu proses transformasi dari suatu input dalam domain fuzzy ke suatu output dalam domain fuzzy. adapun yang digunakan dalam Teknik penalaran adalah teknik penalaran MAX-MIN sebagai logika pengambil Rekomendasi.(Sofwan, 2005).

\section{Fuzzifikasi}

Fuzzifikasi adalah proses pemetaan nilai input dan output menjadi himpunan fuzzy. Proses fuzzifikasi ini yang menjadi perhatian adalah nilai input dan output serta fungsi keanggotaan /Membership function yang digunakan dalam menentukan nilai fuzzy dari data nilai crisp masukan dan keluaran.(Indrabayu, et al. 2012), dari penelitian yang pernah dilakukan penelitian terdahulu juga dapat disimpulkan bahwa fuzzyfikasi adalah proses untuk membentuk fungsi keanggotaan sehingga dalam proses ini akan diketahui 
nilai derajat keanggotaan yang bernilai 1, 0 atau bernilai fuzzy atau samar .

D. Defuzzifikasi

Dari penelitian Peneliti yang terdahulu defuzzyfikasi adalah proses mengubah nilai fuzzy (kabur) menjadi nilai tegas. Dalam defuzzifikasi ini proses terakhir dalam pencarian hasil dan juga pada tahap ini, penentuan hasil defuzzyfikasi dipengaruhi oleh metode inferensi yang akandigunakan baik itu metode inferensi Sugeno, Mamdani atau yang lainnya.

\section{METODE PENELITIAN}

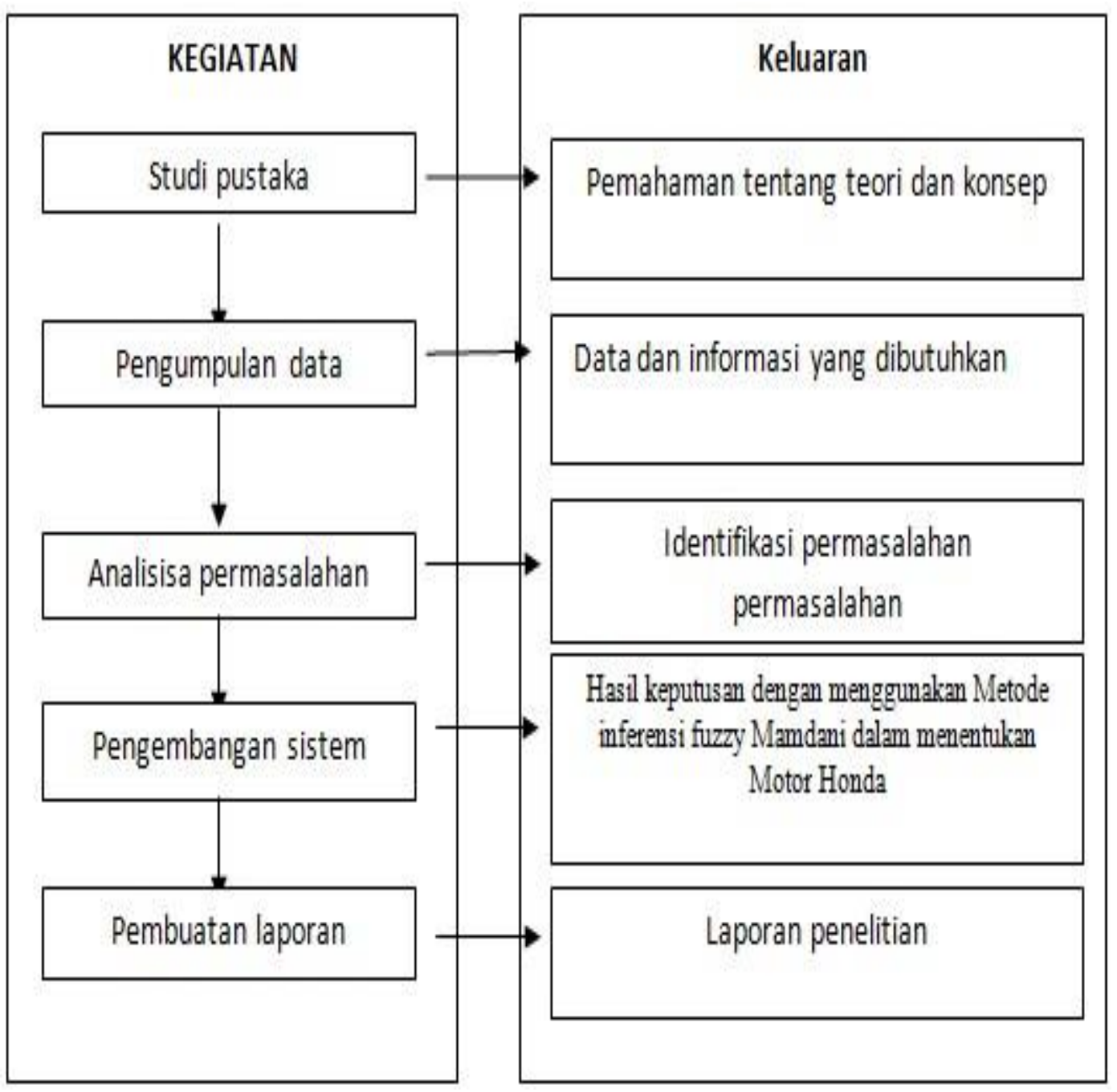

Gambar 2.1. Kerangka Kerja Penelitian

III. HASIL DAN PEMBAHASAN

Untuk menentukan hasil penelitian, penggunaan Matlab sangat mempermudah dalam mendapatkan hasil. Dengan menggunakan matlab diharapkan hasil penelitian ini akan lebih akurat. Adapaun hasilnya sebagai berukut :

3.1 Fungsi Keanggotaan ( membership fungtion)

Variabel-variabel beserta himpunan fuzzy yang digunakan sebagai berikut : 
a. Variabel Harga Beli.

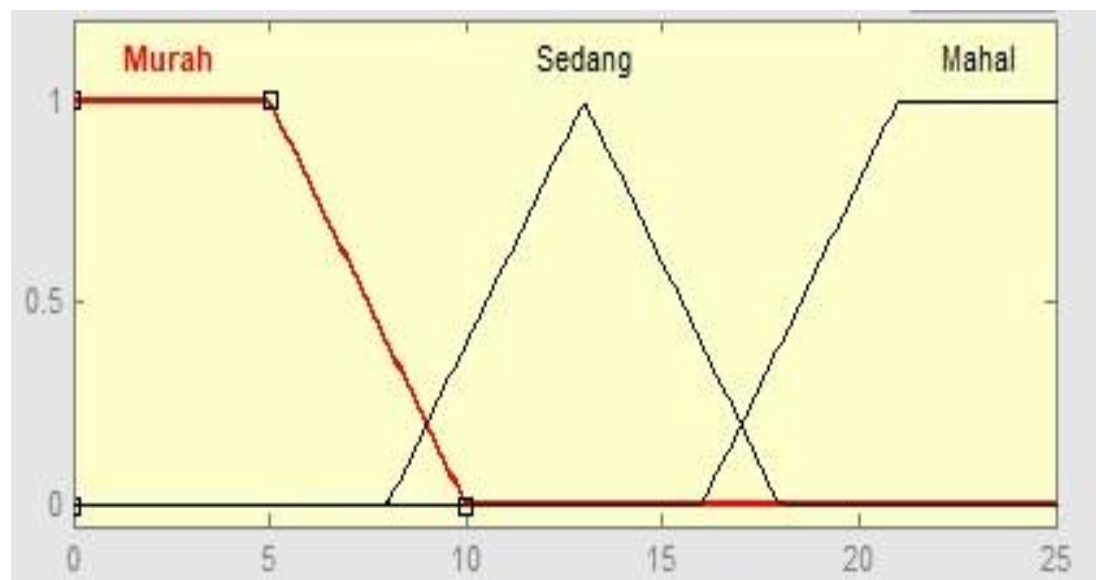

Gambar 3.1 : Fungsi Keanggotaan ( membership fungtion) Harga Beli

b. Variabel Stock

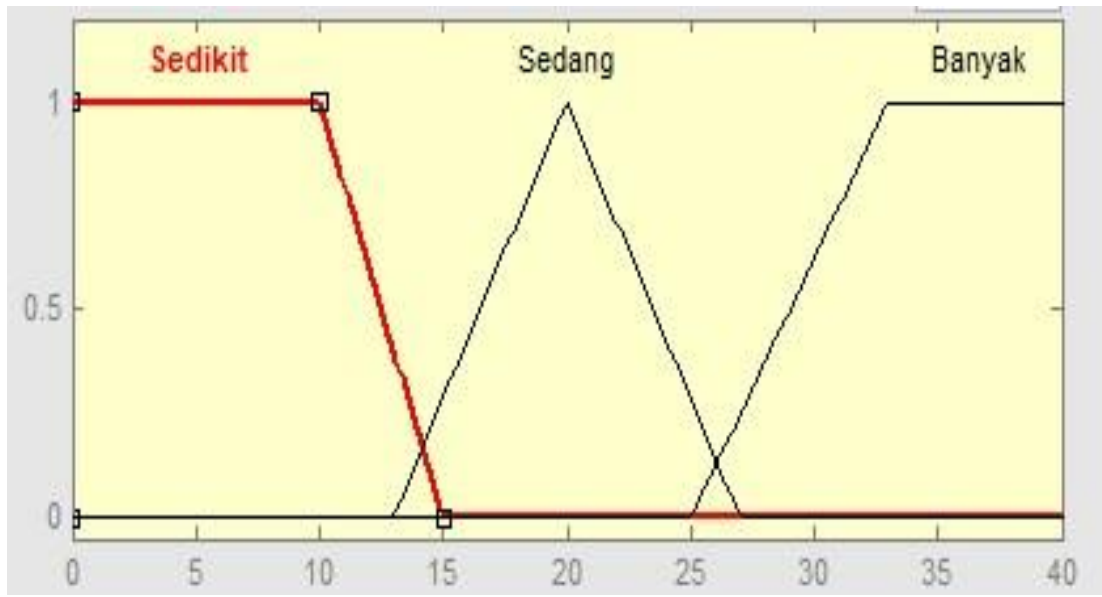

Gambar 3.3 : Fungsi Keanggotaan ( membership fungtion) Stock

c. Variabel Minat Pasar.

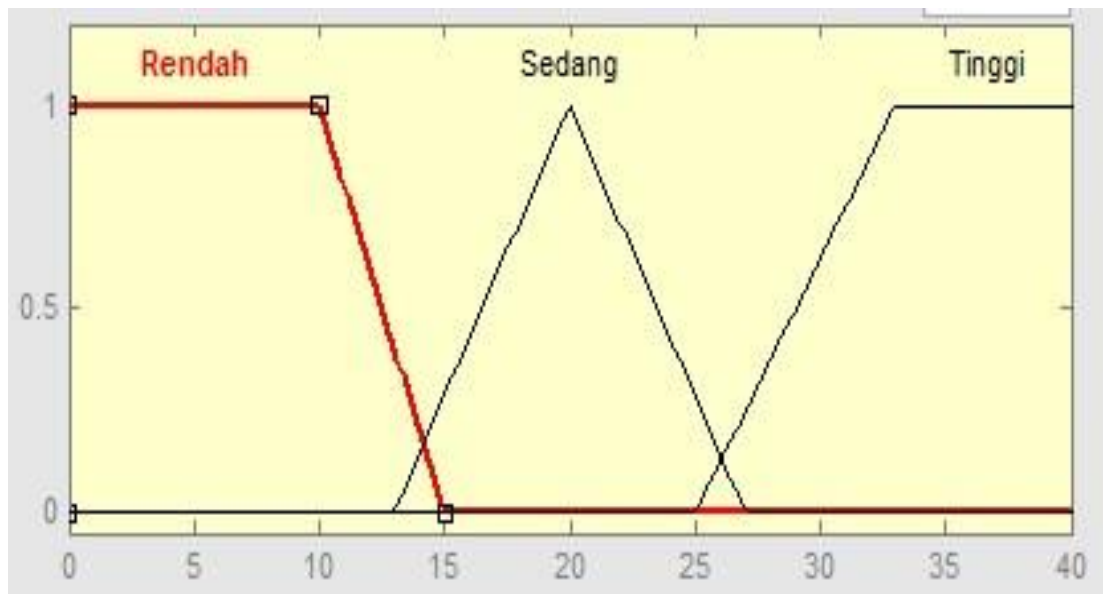

Gambar 3.3 : Fungsi Keanggotaan ( membership fungtion) Minat Pasar 
d. Variabel Output Rekomendasi.

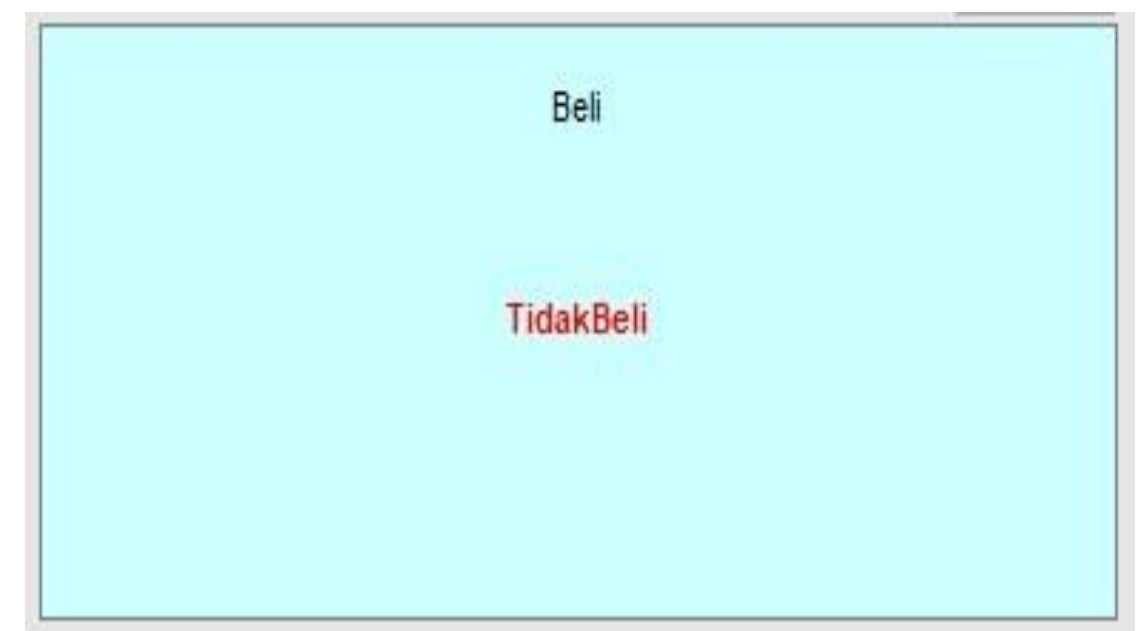

Gambar 3.4 : Fungsi Keanggotaan ( membership fungtion) Output Rekomendasi

\subsection{Fuzzy Rule Base}

Peneltian ini menggunakan aturan rule base sebanyak 27 rule, yaitu:

1. If (HargaBeli is Murah) and (Stock is Sedikit) and (MinatPasar is Rendah) then (Rekomendasi is TidakBeli) (1)

2. If (HargaBeli is Murah) and (Stock is Sedikit) and (MinatPasar is Sedang) then (Rekomendasi is TidakBeli) (1)

3. If (HargaBeli is Murah) and (Stock is Sedikit) and (MinatPasar is Tinggi) then (Rekomendasi is Beli) (1)

4. If (HargaBeli is Murah) and (Stock is Sedang) and (MinatPasar is Rendah) then (Rekomendasi is TidakBeli) (1)

5. If (HargaBeli is Murah) and (Stock is Sedang) and (MinatPasar is Sedang) then (Rekomendasi is TidakBeli) (1)

6. If (HargaBeli is Murah) and (Stock is Sedang) and (MinatPasar is Tinggi) then (Rekomendasi is Beli) (1)

7. If (HargaBeli is Murah) and (Stock is Banyak) and (MinatPasar is Rendah) then (Rekomendasi is TidakBeli) (1)

8. If (HargaBeli is Murah) and (Stock is Banyak) and (MinatPasar is Sedang) then (Rekomendasi is TidakBeli) (1)

9. If (HargaBeli is Murah) and (Stock is Banyak) and (MinatPasar is Tinggi) then (Rekomendasi is Beli) (1)

10. If (HargaBeli is Sedang) and (Stock is Sedikit) and (MinatPasar is Rendah) then (Rekomendasi is TidakBeli) (1)

11. If (HargaBeli is Sedang) and (Stock is Sedikit) and (MinatPasar is Sedana) then (Rekomendasi is TidakBeli) (1)

12. If (HargaBeli is Sedang) and (Stock is Sedikit) and (MinatPasar is Tinggi) then (Rekomendasi is Beli) (1)

13. If (HargaBeli is Sedang) and (Stock is Sedang) and (MinatPasar is Rendah) then (Rekomendasi is TidakBeli) (1)

14. If (HargaBeli is Sedang) and (Stock is Sedang) and (MinatPasar is Sedang) then (Rekomendasi is TidakBeli) (1)

15. If (HargaBeli is Sedang) and (Stock is Banyak) and (MinatPasar is Rendah) then (Rekomendasi is TidakBeli) (1)

16. If (HargaBeli is Sedang) and (Stock is Banyak) and (MinatPasar is Sedang) then (Rekomendasi is TidakBeli) (1)

17. If (HargaBeli is Sedang) and (Stock is Banyak) and (MinatPasar is Tinggi) then (Rekomendasi is Beli) (1)

18. If (HargaBeli is Sedang) and (Stock is Sedang) and (MinatPasar is Tinggi) then (Rekomendasi is Beli) (1)

19. If (HargaBeli is Mahal) and (Stock is Sedikit) and (MinatPasar is Rendah) then (Rekomendasi is TidakBeli) (1)

20. If (HargaBeli is Mahal) and (Stock is Sedikit) and (MinatPasar is Sedang) then (Rekomendasi is TidakBeli) (1)

21. If (HargaBeli is Mahal) and (Stock is Sedikit) and (MinatPasar is Tinggi) then (Rekomendasi is TidakBeli) (1)

22. If (HargaBeli is Mahal) and (Stock is Sedang) and (MinatPasar is Rendah) then (Rekomendasi is TidakBeli) (1)

23. If (HargaBeli is Mahal) and (Stock is Sedang) and (MinatPasar is Sedang) then (Rekomendasi is TidakBeli) (1)

24. If (HargaBeli is Mahal) and (Stock is Sedang) and (MinatPasar is Tinggi) then (Rekomendasi is Beli) (1)

25. If (HargaBeli is Mahal) and (Stock is Banyak) and (MinatPasar is Rendah) then (Rekomendasi is TidakBeli) (1)

26. If (HargaBeli is Mahal) and (Stock is Banyak) and (MinatPasar is Sedang) then (Rekomendasi is TidakBeli) (1)

27. If (HargaBeli is Mahal) and (Stock is Banyak) and (MinatPasar is Tinggi) then (Rekomendasi is Beli) (1)

Gambar 3.5: Rule Base motor Honda 


\subsection{Rule Viewer}

Dalam tahap ini, peneliti masuk pada tahap rule viewer.

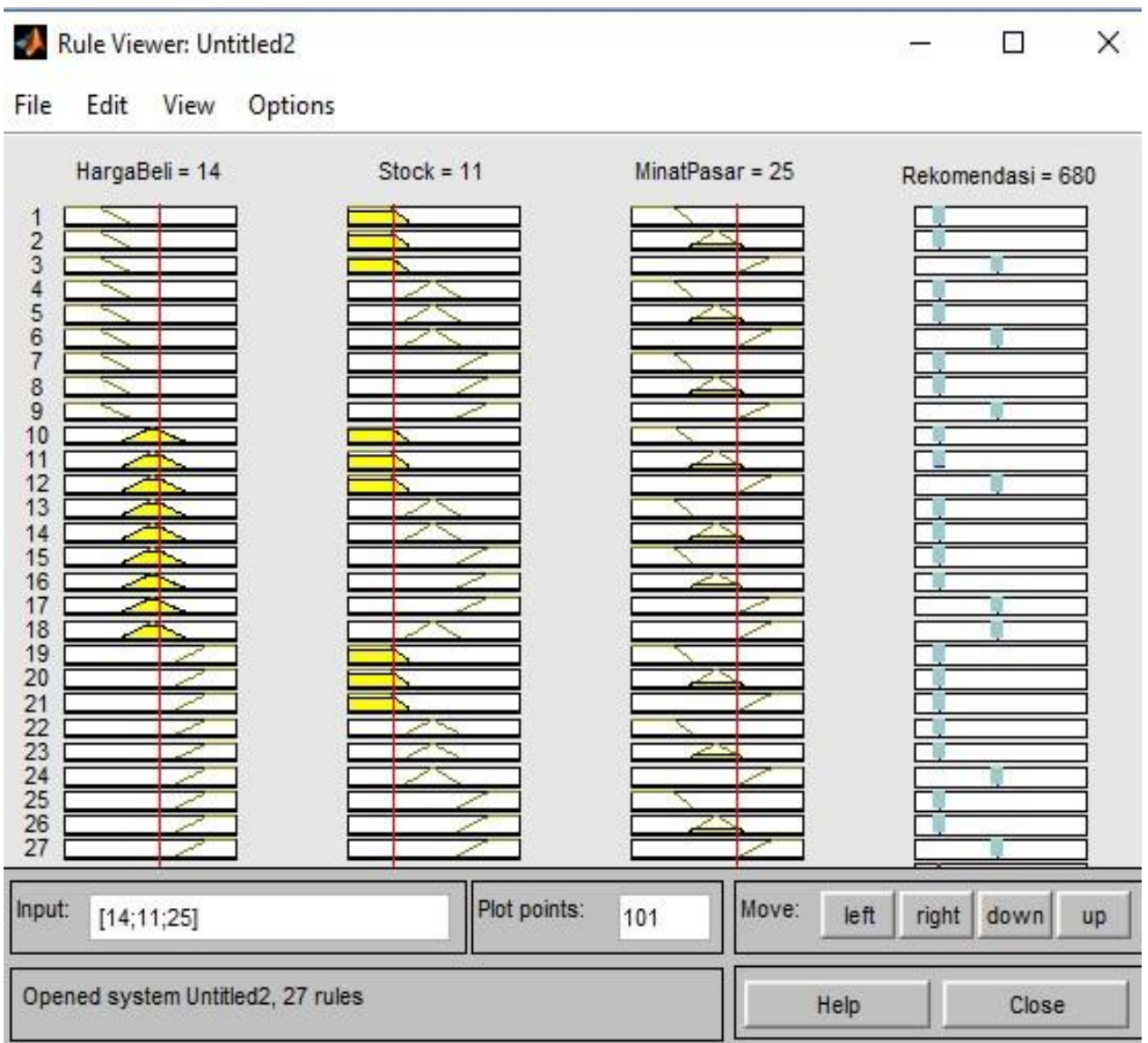

Gambar 3.6: Rule Viewer motor Honda

\subsection{Hasil}

Dalam penelitian ini, untuk menentukan analisis fuzzy sugeno dalamm enentukan pemilihan motor Honda menggunakan Aplikasi matlab.

\section{KESIMPULAN}

Dengan menggunakan inferensi fuzzy Sugeno dapat diterapkan dalam Menentukan pemilihan motor Honda, sehingga bagi masyarakat yang tertarik dalam membeli sepeda motor Honda dapat menggunakan fuzzy sugeno ini sebagai perbandingan dengan metode mamdani yang telah dilakukan oleh peneliti terdahulu. Dan dari perbandingan antar mamdani dan sugeno hampir memiliki hasil yang sama dalam menyelesaikan kasus pemilihan sepeda motor hinda tersebut.

\section{DAFTAR PUSTAKA}

(1) Hosseinzadeh, B., Zareiforoush, H., Adabi, M. E. \& Motevali, A. 2011.Development of a Fuzz y Model to Determine the Optimum Shear Stre ngth of Wheat Stem. International Journal of C omputer Science and Telecommunications2(4): 56-60.

(2) Indrabayu., Harun, N., Pallu, M.S., Andani, A. \& Febriyati, F. 2012. Sistem Pendukung Reko mendasi Seleksi Anggota Paduan Suara Dewas a Menggunakan Metode Fuzzy Mamdani.Semin ar Nasional Matematika dan Pendidikan Mate matika.pp. 55-66

(3) Januardi Nasir dan Johnson Suprianto. 2017. A nalisis Fuzzy Logic Menentukan Pemilihan Mo tor Honda Dengan Metode Mamdani. Jurnal Ed ik Informatika. V3.i2

(4) Kusumadewi, S. \& Purnomo, H. 2010. Aplikas i Logika Fuzzy untuk Pendukung Rekomendasi . Graha Ilmu: Yogyakarta.

(5) Nasution, H. 2012. Implementasi Logika Fuzzy pada Sistem Kecerdasan Buatan.Jurnal ELKH A4(2): 4-8. 
(6) Sofwan, A. 2005.Penerapan Fuzzy Logic Pada Sistem Pengaturan Jumlah Air Berdasarkan Suh u Dan Kelembaban.Seminar Nasional Aplikasi Teknologi Informasi.pp..

(7) Sutojo, T., Mulyanto, E., \& Suhartono, V. 201 1. Kecerdasan Buatan, Penerbit Andi, Yogyak arta.
(8) Zadeh, L.A. 1990. Fuzzy Sets And Systems. Int ernational Journal of General Systems.17(2): 1 29-138. 